\title{
Diagnosis of Multiple Myeloma from a Blood Sample Failed To Be Centrifuged: A Case Report
}

\author{
Limin Zhang ${ }^{1}$, Hong Lv', Kelin Chen'1, Fang Fang², Ruimin Ma', Guanghui Zheng' ', Jingzheng Liu', Chunqing Shao',
} Bei Song ${ }^{1}$, Hui Zhao', JunpingWang ${ }^{3}$, Xixiong Kang ${ }^{1}$, Guojun Zhang ${ }^{1,+}$

\section{Keywords}

Multiple Myeloma, Blood

\begin{abstract}
Introduction
Multiple myeloma (MM) is a plasmocyte malignant proliferative disease $[1,2]$. It causes dysplasia of clonal plasmocyte in marrow, brings the secretion of monoclonal immune globulin or its fragment (M protein), inducing related organs or tissues lesion. MM has a diversity of clinical features such as anemia, ostealgia, kidney failure, infection, hemorrhage and so on [3], so they result in misdiagnosis easily, thus laboratory examinations are very essential for differential diagnosis. Now we will introduce a typical case of MM with a special blood sample.
\end{abstract}

July 30th, 2016, clinical laboratory in emergency, we received three tubes of blood sample from a patient for blood routine test, biochemistry test and thrombotest. The last two tubes were centrifuged to get serum and plasma separately. While an erratic phenomenon occurred: the sample for biochemistry test couldn't be centrifuged to obtain serum successfully, which contained a separating gel but no anticoagulation, there was little serum but too much haematocyte. On the contrary, the one for thrombotest which contained anticoagulation of potassium citrate got too much plasma but little haematocyte (Figure 1A). In addition, the blood routine test showed the hemoglobin was only $55 \mathrm{~g} / \mathrm{L}$, which revealed severe anemia. So it seemed inconsistent from the data above. More data were needed to make diagnosis.

\section{Case Presentation}

A 60-year-old male presented to his physician on July, 30th, 2016 complaining of fatigue, generalized weakness, dyspnea upon minimal exertion for one year, which was aggravated with dizziness in the late month. His vital signs were as follows: blood pressure 129/82 $\mathrm{mmHg}$, pulse $82 / \mathrm{min}$, breathing $20 / \mathrm{min}$, body temperature $36.4^{\circ} \mathrm{C}$. Routine laboratory values of major significance revealed hemoglobin levels of about $5.5 \mathrm{~g} / \mathrm{dL}$ (reference 11-16) and his platelets count at $102,000 / \mathrm{mL}$ (reference 100,000-300,000/ $\mathrm{mL}$ ) (Figure 1B). The patient was referred to the emergency department at Capital Medical University, Beijing Tiantan Hospital for bone marrow biopsy and a hematology consult. Upon admission, it was noted that his blood samples were weird as showed above.

\section{- Laboratory examination}

After discussion, we decided to use a blank tube for biochemistry test as we couldn't get serum successfully using the tube containing separation gel. It was useful! The results were as follows (Figure 2): the total protein (TP) and globulin (GLB) levels were elevated to $123 \mathrm{~g} / \mathrm{L}$ (reference 60-80) and $95.3 \mathrm{~g} / \mathrm{L}$ (reference 20 30 ), the albumin(ALB) level was decreased to $27.7 \mathrm{~g} / \mathrm{L}$ (reference 35-55). On the next day the results of serum protein electrophoresis revealed

\footnotetext{
'Laboratory Diagnosis Center, Beijing Tiantan Hospital, Capital Medical University, Beijing, China

${ }^{2}$ Monogenic Disease Research Center for neurological Disorders, Beijing Tiantan Hospital, Capital Medical University, Beijing, China

${ }^{3}$ Internal medicine Department II, Gucheng hospital, Hebei Province, China

${ }^{\dagger}$ Author for correspondence: Guojun Zhang, Laboratory Diagnosis Center, Beijing Tiantan Hospital, Capital Medical University, Beijing 100050, China, Tel: +86 10 67096881; Fax: 010-67096877; email: tiantanlab@163.com
} 


\section{Case Report Guojun Zhang}

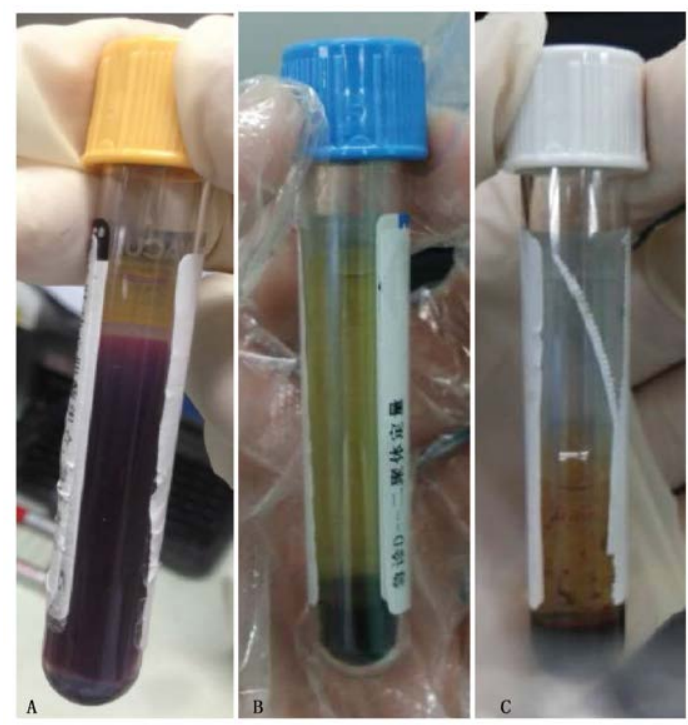

Figure 1A: Three tubes of blood sample. Tube A for biochemistry test, with separation gel but no anticoagulation. Tube B for thrombotest, with anticoagulation of potassium citrate. Subtitute tube $\mathrm{C}$ for biochemistry test, with nothing in it. There was little serum but too much haematocyte in tube $A$, while too much plasma but little haematocyte were separated in tube B and C.

\begin{tabular}{|c|c|c|c|c|c|c|c|c|c|}
\hline \multirow{2}{*}{\multicolumn{2}{|c|}{$\begin{array}{c}5850 \\
5850 \\
\text { 姓名: } \\
\text { 科别: 神 }\end{array}$}} & \multicolumn{5}{|c|}{ 北京天坛医院 检验报告单 } & \multicolumn{3}{|c|}{|||||||||||||||||||||||| $\mid$ 血常规 } \\
\hline & & & & & & & & & \\
\hline \multicolumn{2}{|c|}{ 分析项目 } & \multirow{2}{*}{$\begin{array}{l}\text { 结果 } \\
6.39\end{array}$} & \multirow{2}{*}{$\frac{1 \text { 单位 }}{10 \mathrm{E} 9 / \mathrm{L}}$} & \multirow{2}{*}{$\begin{array}{r}\text { 多考范国 } \\
4.00-10.00\end{array}$} & \multicolumn{2}{|c|}{ 分析项目 } & \multirow{2}{*}{$\frac{\text { 结果 }}{102}$} & \multirow{2}{*}{$\begin{array}{l}\text { 单位 } \\
10 \mathrm{E} 9 / \mathrm{L}\end{array}$} & \multirow{4}{*}{$\begin{array}{c}\frac{\text { 参考范围 }}{100-300} \\
115.0-17.0 \\
7.00-11.00\end{array}$} \\
\hline$* \mathrm{WBC}$ & 白䍀胞绝对值 & & & & *PLT & 面小板绝对值 & & & \\
\hline$L Y \equiv$ & 淋巴组胞磁绝对值 & 2.57 & 10E9/L & $0.90-5.20$ & PDW & 血小板分布宽度 & 9.4 & $\mathrm{fL}$ & \\
\hline MONO\# & 单核组胞群绝对值 & 0.78 & $10 \mathrm{E} 9 / \mathrm{L}$ & $0.16-1.00$ & MPV & 平均血小板体积 & 8.30 & $\mathrm{f} 1$ & \\
\hline NEUT \# & 中性粒纵胞绝对值 & 2.97 & $10 \mathrm{E} 9 / \mathrm{L}$ & 2. $00-7.50$ & P-LCR & 大血小板比率 & 14.4 & $\%$ & \\
\hline $\mathrm{EO}=$ & 䀦帷吽细胞绝对值 & 0.06 & $10 \mathrm{E} 9 / \mathrm{L}$ & $0.00-0.80$ & PCT & 血小坂龙积 & 0.080 & $\%$ & \\
\hline $\mathrm{BA}=$ & 㗪酮性细胞统对值 & 0.01 & $10 \mathrm{E} 9 / \mathrm{L}$ & $0.00-0.20$ & & & & & \\
\hline LY\% & 淋巨组胞群相对值 & 40.20 & $\%$ & $20.00-50.00$ & & & & & \\
\hline MO\% & 单㤥缃䐜群相对值 & 12. 20 & $\%$ & $12.00-8.00$ & & & & & \\
\hline GRG & 中怢柆约胞相对值 & 46. 50 & $\%$ & $\$ 50.00-75.00$ & & & & & \\
\hline EO\% & 㗪㹸性细胞相对值 & 0.90 & $\%$ & $0.50-5.00$ & & & & & \\
\hline BA\% & 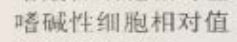 & 0.20 & $\%$ & $0.00-1.50$ & & & & & \\
\hline *RBC & 红纵胞绝对值 & 1.54 & $10 E 12 / \mathrm{L}$ & 13. $50-5.50$ & & & & & \\
\hline *HGB & 牦红柋向 & 55 & $\mathrm{~g} / \mathrm{L}$ & $+110-160$ & & & & & \\
\hline$* \mathrm{HCT}$ & 红细胞片积 & 16. 90 & $\%$ & $.37 .00-50.00$ & & & & & \\
\hline$* \mathrm{MCV}$ & 红组胞均体积 & 109.70 & fl 1 & $180.00-100.00$ & & & & & \\
\hline *MCH & 䏛们红出白军 & 34.40 & pg & $127.00-32.00$ & & & & & \\
\hline *MCHC & 均任红柋山浓度 & 314 & $\mathrm{~g} / \mathrm{L}$ & $+320-360$ & & & & & \\
\hline RDW-SD & 红细胞分布䆓度SD & 46. 20 & $\mathrm{fl}$ & & & & & & \\
\hline $\mathrm{RDW}-\mathrm{CV}$ & 红纵胞分布究度 CV & 12.30 & $\%$ & 10. $10-16.00$ & & & & & \\
\hline & 医 师: & & & $m m$ & $n$ & 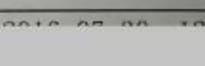 & & & \\
\hline & 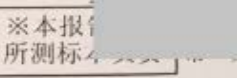 & & & & & & & & \\
\hline
\end{tabular}

Figure 1B: Routine blood cell test hinted severe anemia.

the levels of albumin, globulin of Alpha1a, $\beta$ 1and $\beta 2$ decreased, while $\gamma$ globulin increased to $47.3 \%$ ( reference $10.3-18.2$ ), $\mathrm{A} / \mathrm{G}$ ratio was 0.54(reference 1.10-2.40) (Figure 3). Further test for immunoglobin level was as follows (Figure 4). $\mathrm{IgE} 4.63 \mathrm{IU} / \mathrm{ml}$ (reference $0-200$ ), $\mathrm{IgG} 84.10 \mathrm{~g} / \mathrm{L}$ ( reference 7-16), IgA0.23 g/L( reference 0.7-4) ,IgM $0.18 \mathrm{~g} / \mathrm{L}$ ( reference $0.4-2.3$ ). 


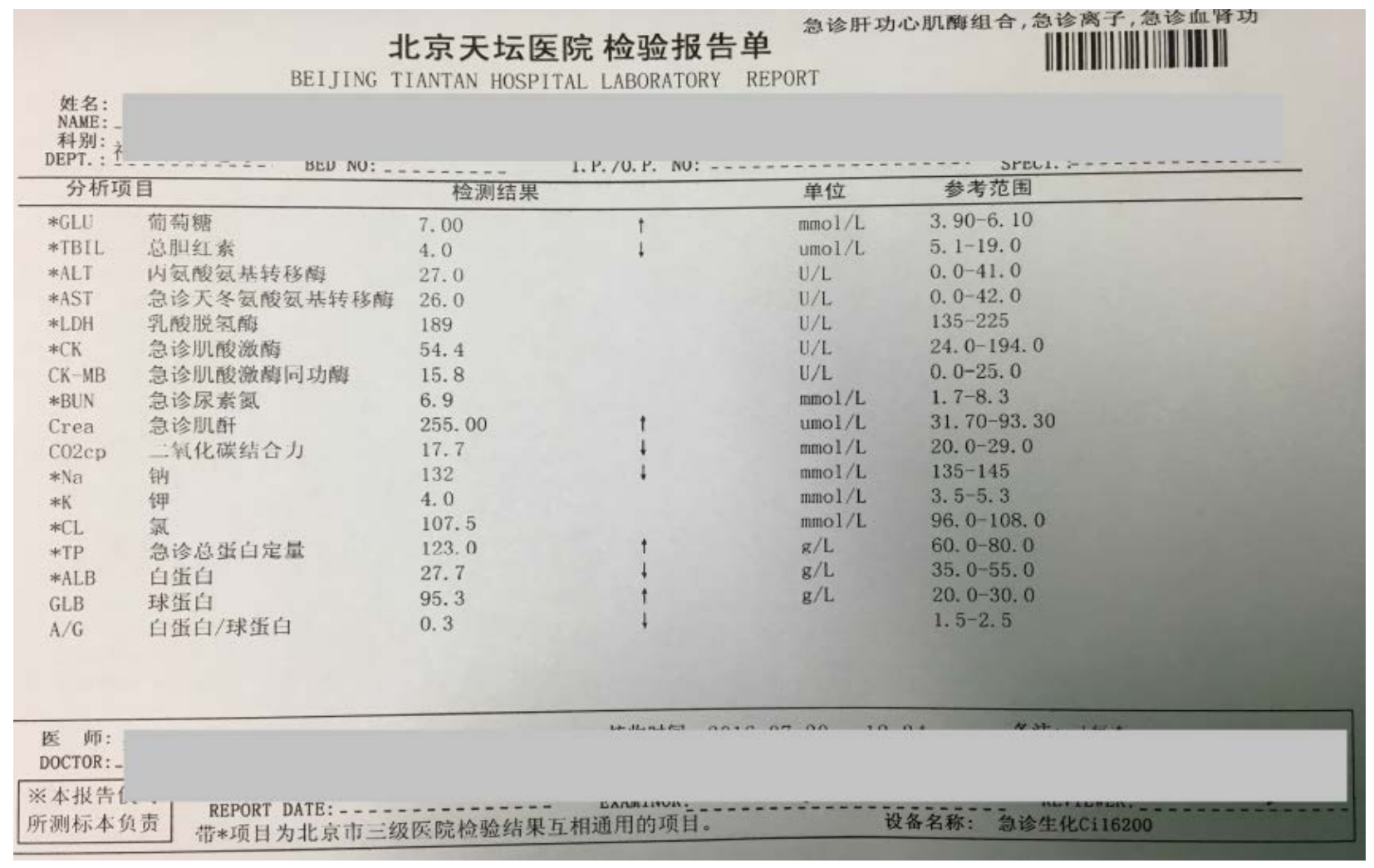

Figure 2: Results of biochemistry test. High level of TP and GLB, low level of ALB. The A/G was in inverse ratio.

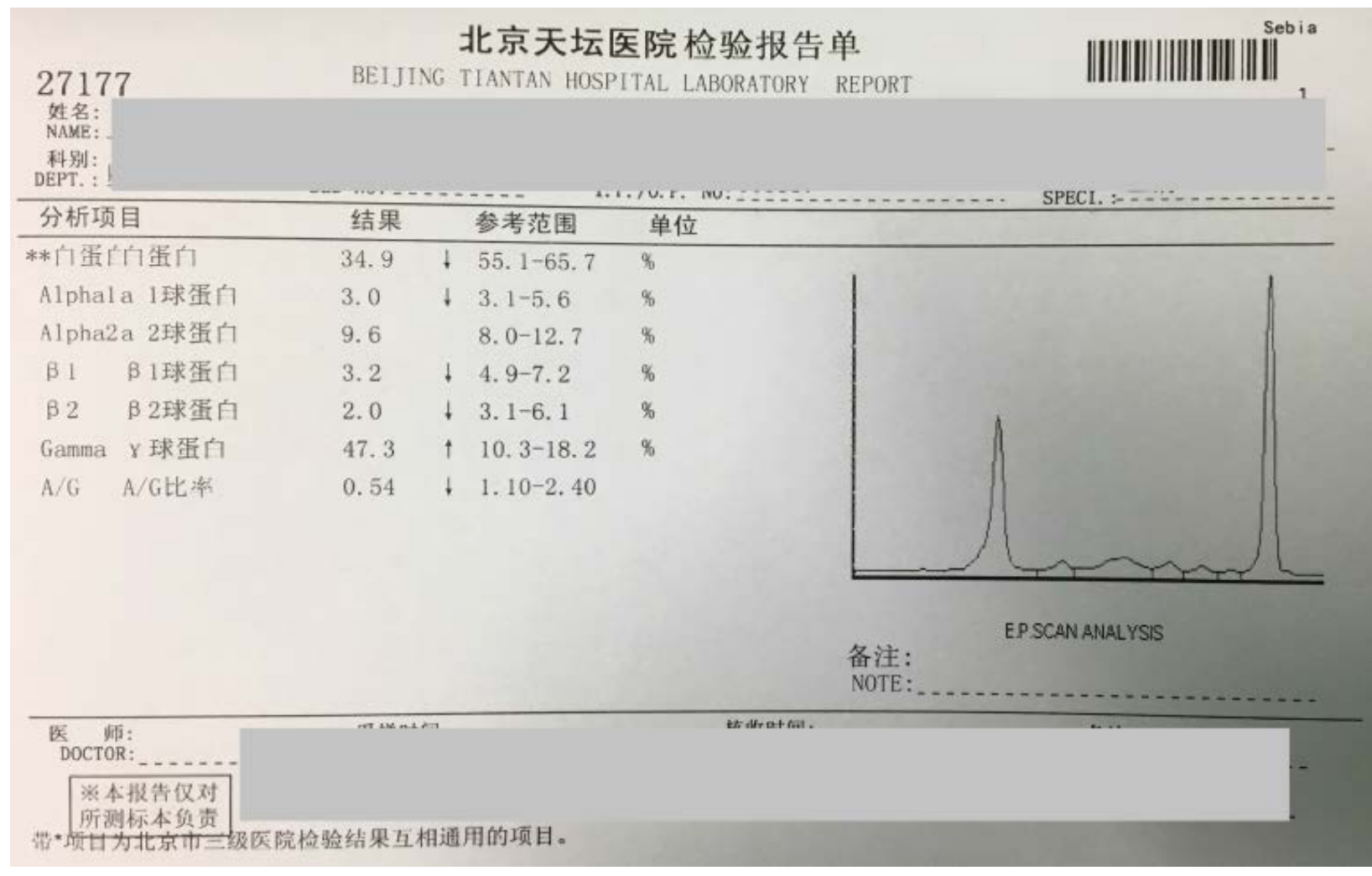

Figure 3: The results of serum protein electrophoresis. There was a sharp wave in $\gamma$ globulin region. 


\section{Case Report Guojun Zhang}

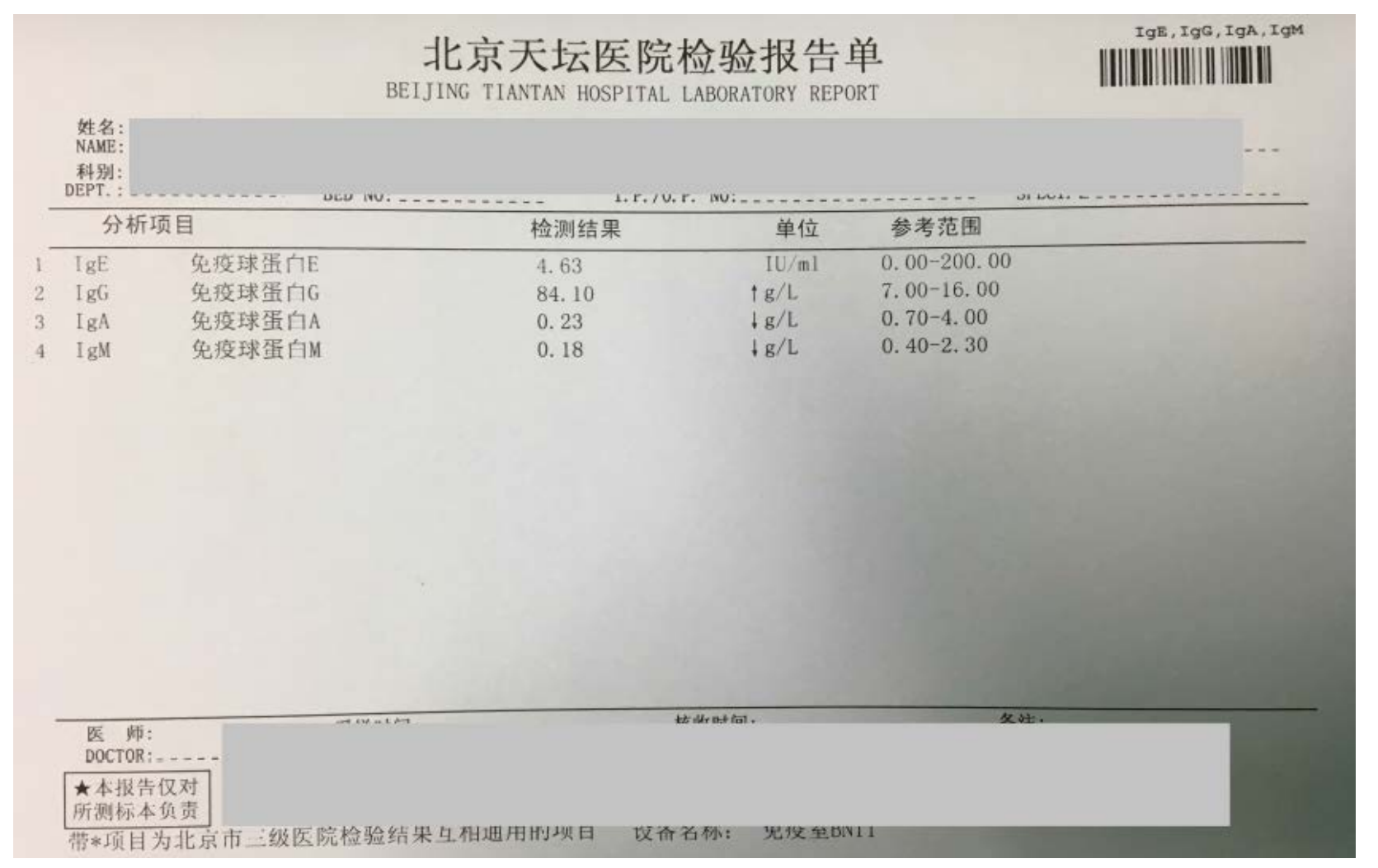

Figure 4: Results of immunoglobin level. The $\lg G$ was $84.10 \mathrm{~g} / \mathrm{L}$, exceeding the normal level several times.

According to the test results above, we made a primary conclusion that the patient may be attacked by the disease of MM. In order to make clear the type of the disease, we detected $M$ protein with the method of immune electrophoresis; the result revealed that the type of $\mathrm{M}$ protein was IgG/Kappa (+) (Figure 5). At the same time, a peripheral blood smear revealed abnormal plasma cells and a $42 \%$ distribution of lymphocytes, with $2 \%$ being plasma cells (Figure 6A, 6B). Additionally the results of the bone marrow biopsy revealed a Grade II hyper cellular marrow and $68.5 \%$ plasma cells, while only $14.5 \%$ granulocyte and $8.5 \%$ erythrocyte (Figure 7). Given all of the above information, a definitive diagnosis of MM was made.

\section{- Clinical manifestations}

MM is a primary plasma cell malignancy characterized by extensive osteolytic destruction. It has an incidence of 4 of 100,000 habitants/ year in the Western World with a male to female ratio of 1.6: 1 [2,4]. Most patients are more than 40 years old. MM is characterized by abnormal proliferation of bone marrow plasma cells associated with monoclonal immunoglobulin or light chain ( $\mathrm{M}$ protein) over-generation. As MM usually has a chronic onset with atypical symptoms at early stage, so it was easily misdiagnosed. MM has a diversity of clinical manifestations such as anemia, bone pain, kidney damage [5], bleeding, neurological symptoms, hypercalcemia, amyloidosis and so on. As the formation of normal immunoglobulin is inhibited, so the patients are prone to a variety of bacterial infections. As showed above, this case we reported presenting with fatigue, generalized weakness, dyspnea upon minimal exertion and left shoulder pain of three-months duration, had nose bleeding four times with no obvious risk factors two weeks ago, which was hard to stop. Clinical examinations were as follows: anemic countenance, cadaverous eyelid conjunctiva and breastbone with no pain. Lung breath sounded clear with regular heart thythm, and abdomen was plain and soft with no tenderness.

\section{Discussion}

As mentioned at the start, blood sample tubes that contain a separating gel are often used to obtain blood serum for laboratory tests. After centrifugation, the inert acrylic gel at the bottom of the tube normally occupies the middle 


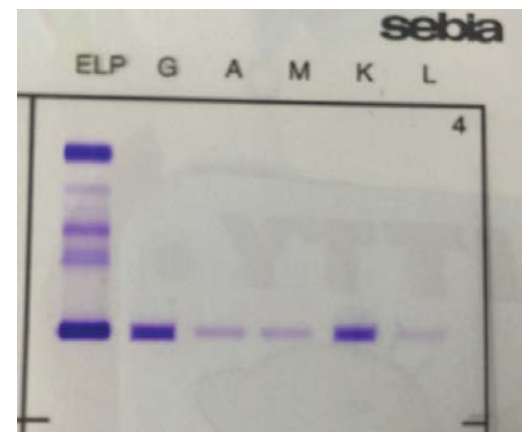

Figure 5: Immune electrophoresis. The type of M protein was IgG/Kappa (+).

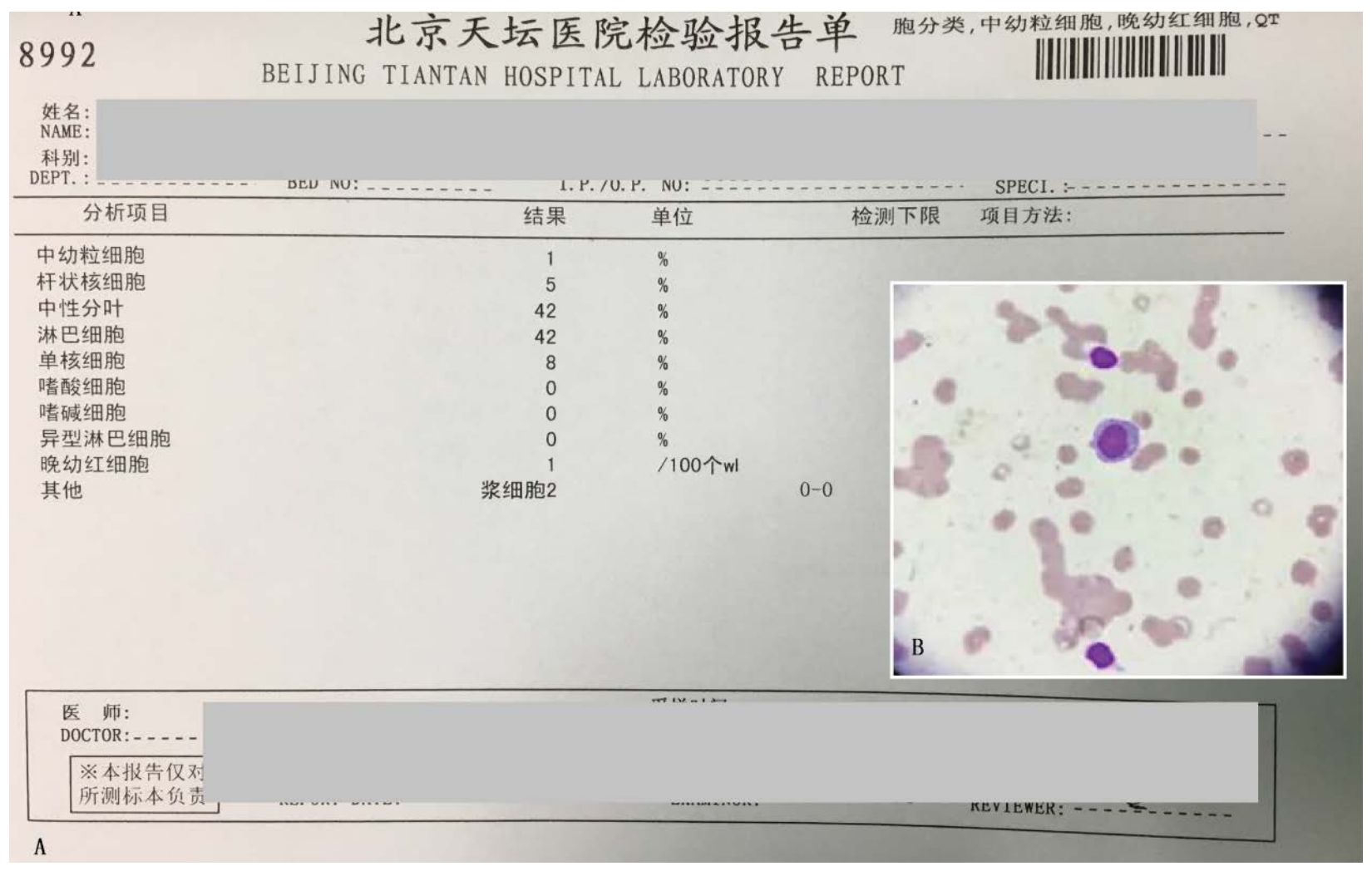

Figure 6: Peripheral blood smear showed abnormal plasma cells and the red blood cells were in a form of rouleaux.

position between the cells (clot) and the serum, as its density is intermediate between theirs. The gel then serves as a barrier to diffusion, preventing contamination of the serum with cellular components. The reason for the failure of obtaining serum despite correct centrifugation may be as follows: there was a lot of globulin in the blood, which was a kind of macromolecule with large diameter, as it couldn't pass through the separation gel, serum couldn't be separated successfully. But some people had different opinion: Maire B considered hyperproteinemia made the serum denser than the separating gel, which therefore lay on the top of the serum fraction during centrifugation [6]. Thus it gave us a false appearance that there was too much erythrocyte as if the patient suffered from the disease of polycythemia. But in fact the hemoglobin concentration was very low, only $55 \mathrm{~g} / \mathrm{L}$. So there was, in fact, no conflict. As the body produces a large number of invalid immunoglobulin, which can increase blood viscosity, so thrombosis occurs. At the same time, the abnormal immunoglobulin can be wrapped in the surface of platelets and coagulation factors, affecting the formation of blood clots, which induces 


\section{Case Report Guojun Zhang}

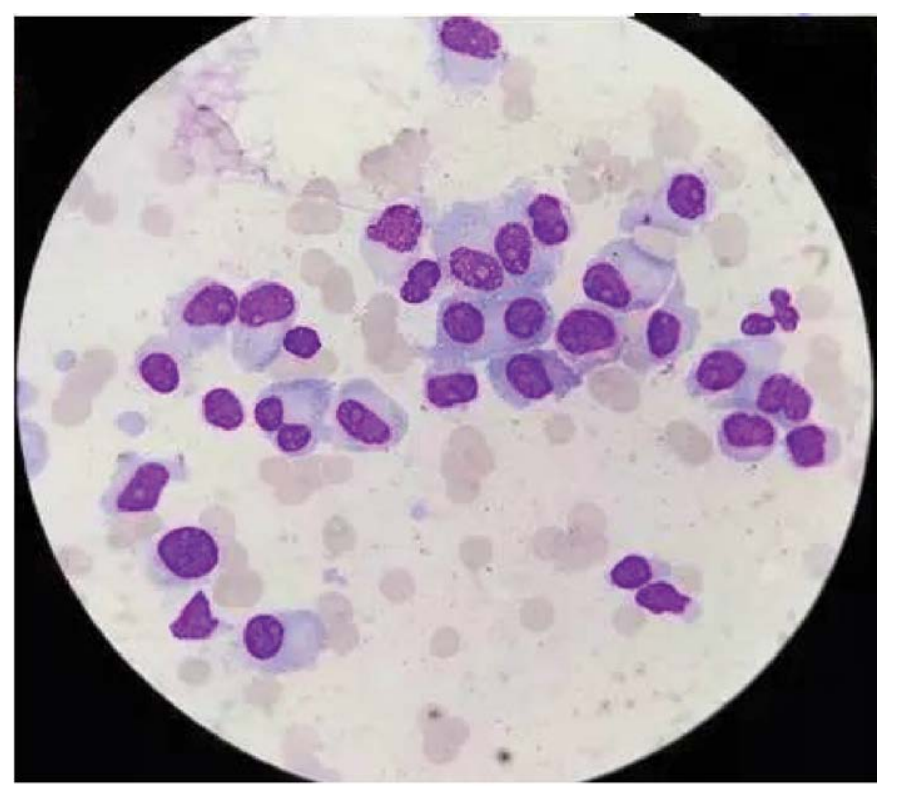

Figure 7: Bone marrow examination microscopically showed dense plasma cells. Mature and relative mature nuclei are round or ovoid, of the same size, often offset.

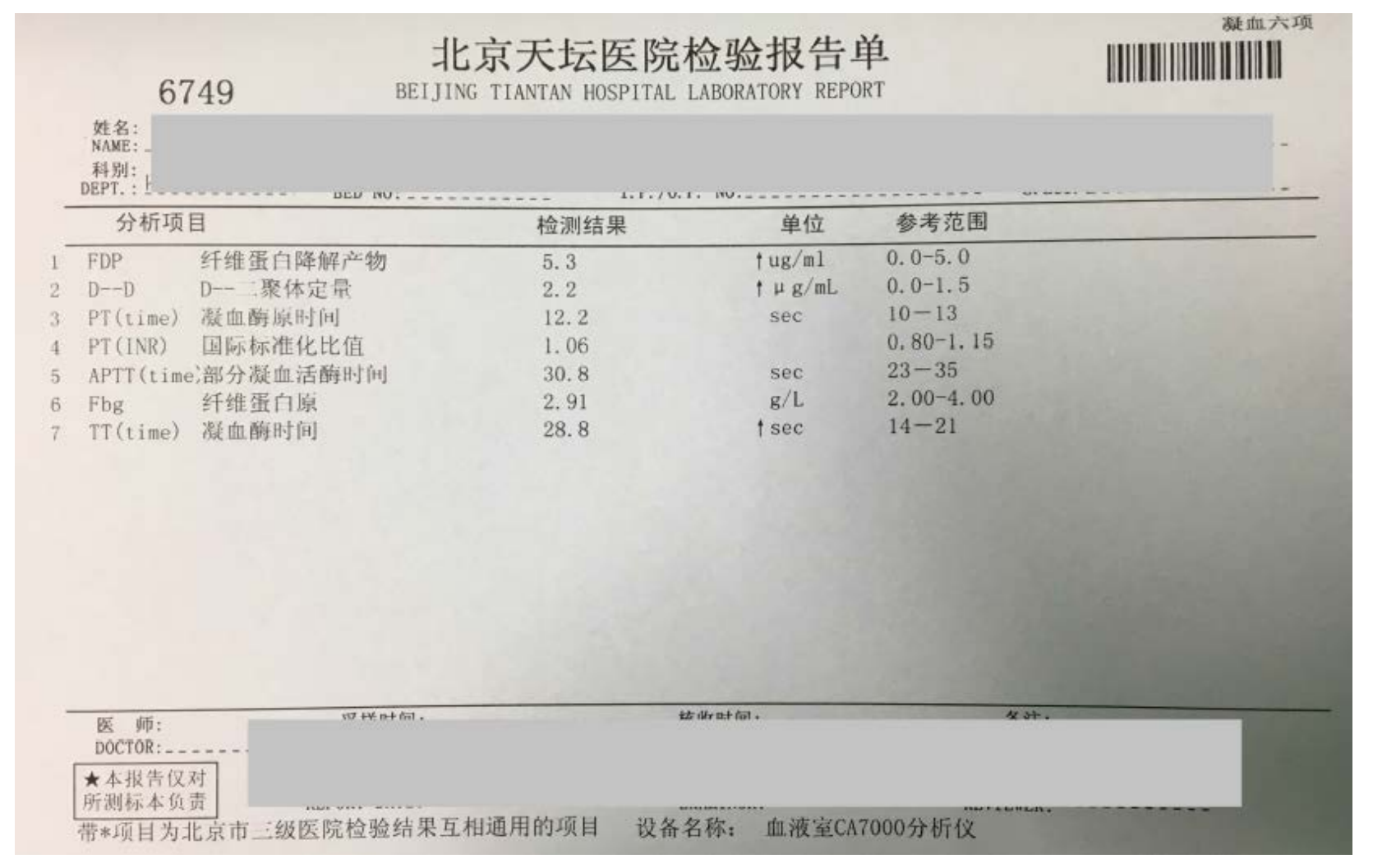

Figure 8: Thrombotest revealed a disturbance of blood coagulation with a prolonged TT.

human bleeding [7]. That was why the patient had nose bleeding hard to stop with a longer thrombin time of 28.8 seconds (reference 14-21) (Figure 8). Hyperglobulinemia can also result in an increase of ESR. This case showed a high ESR of more than $140 \mathrm{~mm} / 60 \mathrm{~min}$ (reference $0-15$ ). As globulin has a positive charge, it can promote the aggregation of erythrocyte and accelerate 


\section{Diagnosis of Multiple Myeloma from a Blood Sample Failed To Be Centrifuged: A Case Report Case Report}

ESR by neutralizing the negative charge on the surface of the red blood cells [7]. In many cases, as the clinical symptoms and signs are not typical, misdiagnose always occurs. Patients were often admitted in respiratory ward, renal ward or orthopaedic ward besides hematology ward due to hemoptysis, proteinuria or bone fracture.

This phenomenon is seen in very advanced cases of myeloma; as an iatrogenic effect after the administration of iodinated radiologic contrast media; and in dialysis patients, when blood is taken from catheter systems in which a concentrated sodium citrate solution is used as a blocking solution. This case reminds us to consider multiple myeloma whenever this phenomenon is seen [6]. Then we can do further test of $\mathrm{M}$ protein to make a definite diagnosis, thus it can be seen laboratory diagnosis plays a very important role during the diagnosis of some diseases. Laboratory and clinical diagnosis have both division and cooperation during the diagnosis and treatment of diseases. Our laboratory workers are more likely to get the first hand data than the clinician. If we can discover problems in our daily life, communicate with doctors and nurses actively, propose further checks, and finally find the answers following the clues, not only the patients can get diagnosis and treatment as soon as possible, but also we have a sense of achievement.

\section{References}

1. Rajkumar SV, Kumar S. Multiple myeloma: diagnosis and treatment. Mayo.Clin. Proc 91(1), 101-119 (2016).

2. Dash NR, Mohanty B. Multiple myeloma: a case of atypical presentation on protein electrophoresis. Indian J. Clin. Biochem 27(1), 100-102 (2012).

3. Williams GD, Kadaria, Sodhi A. Concurrent myelomatous pleural effusion and extramedullary mediastinal involvement as an initial manifestation of multiple myeloma. Am. J. Case Rep 17(1), 472-475 (2016).

4. Ribeiro IS. Hematologia da Pratica Clinica à Teoria. Lidel, Lisboa (2015).

5. Mariana Alves, Raul Moreno, Fatima Rodrigues, et al. Hematuria as the first sign of multiple myeloma. Clinical. Case. Reports 5(8), 1358-1361 (2017).
6. Maire B, Schlüter K. A problem with the separating gel in a blood sample tube in a patient with multiple myeloma. Dtsch. Arztebl. Int 114(1), 507 (2017).

7. Li Wen-ke, Li Wen-qian,Feng Jian-ming, et al. Clinical significance of determination of C-reactive protein, hemoglobin, erythrocyte sedimentation rate in the different stages of patients with multiple myeloma. Journal. Of. Leukemia \& Lymphoma 21(3), 167-170 (2012). 